\title{
植物精油の生機發生學的研究（第十三報) 植物生體內に注入せるシトラールの變化
}

(睢和十八年五月㙇一日变領)

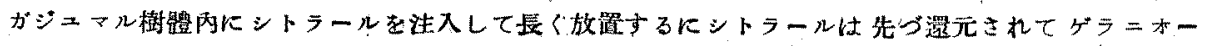
ル上なり, 更にてーシトロネロールを生じ, 父別にダランオールは一部メチループテノンをなり, 更に還 元さ机てdーメチルへプテノールとなる。

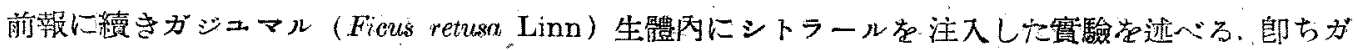

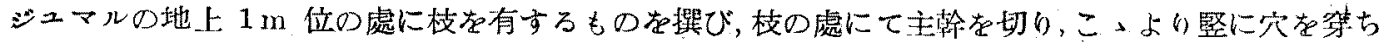

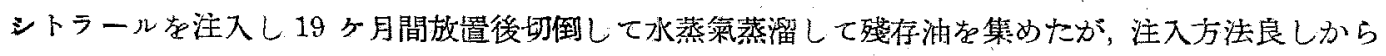
ず、消失極めて多く殘留油分は注入量の $8 \%$ に過ぎなかつた.

油分は檢索の結果主としてゲラニオール及びしシトロネロールよりなり, 叉小量のメチルヘプテ，

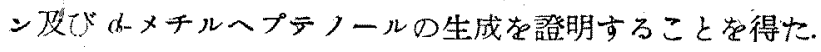

光學的に不活性なるシトラールからにシトロネロール及び かメチルヘプテノールの如き光學的活 性物灰得らことは生體內反應として極めて興味あることである。

以上によりがジニマル生體冈に起るシトラールの生化學的酸化還元は次の加き樣式に從ふものな ろこと知る

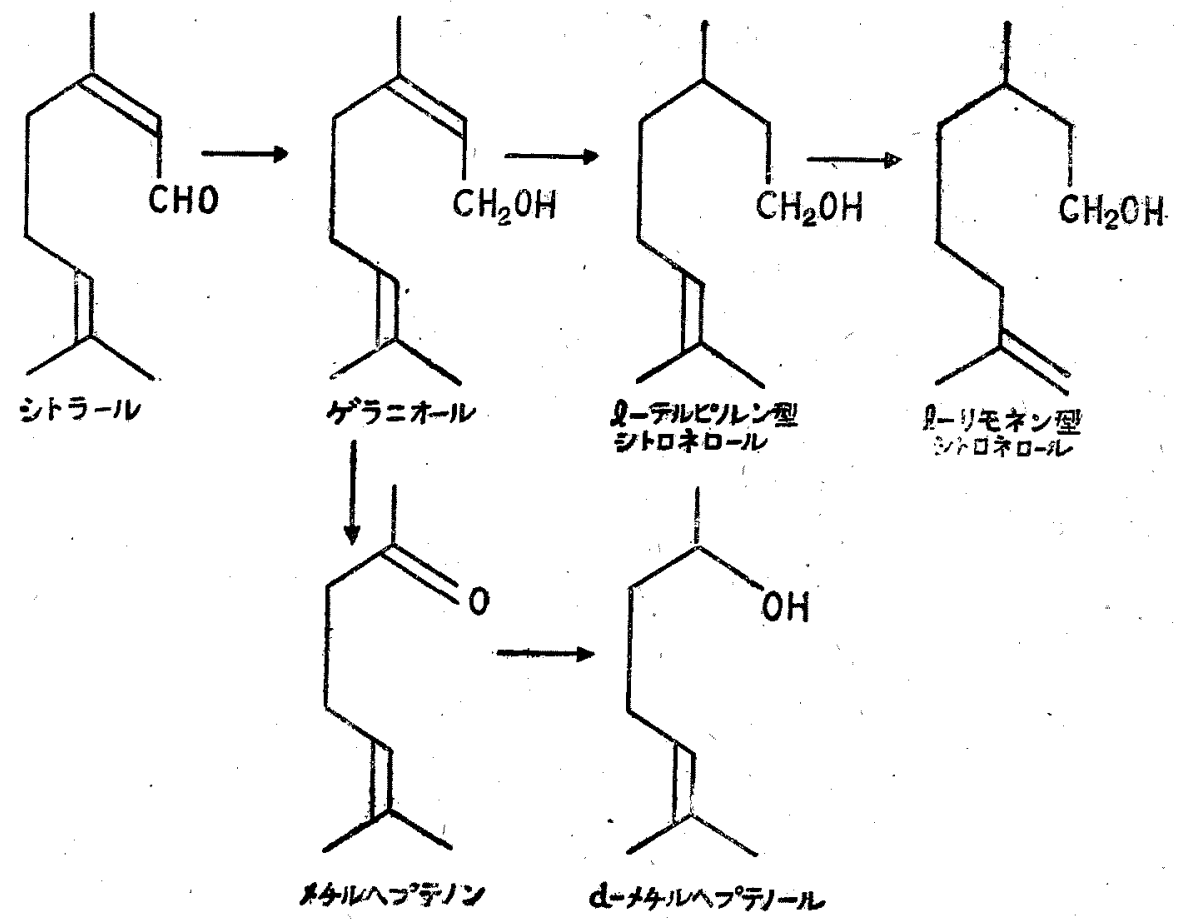


このことにより多くのシトラール,ゲラニオール含有精油中に等しくメチルヘブテノンの共存する 所以知ることが出來る。

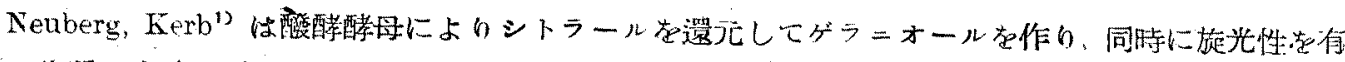

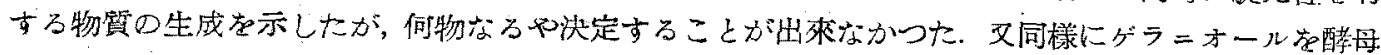

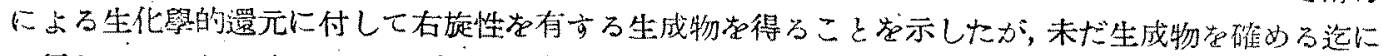

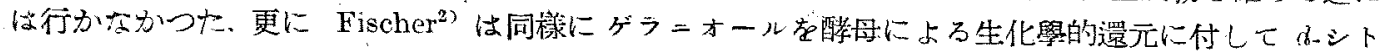

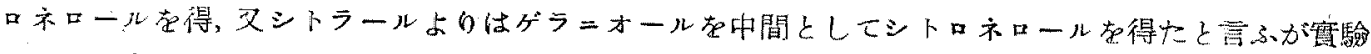

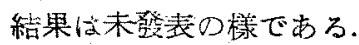

叉 Neuberg, Lewite フール起得てるる。

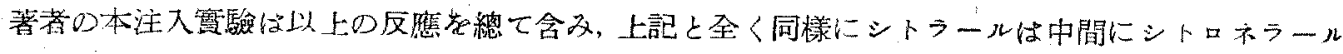

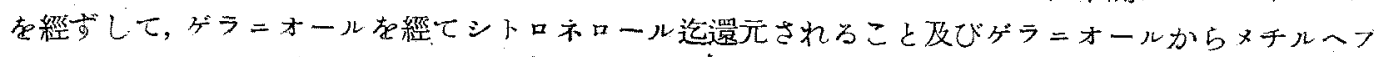
テンン小酸化的分解が起 ๖ことが出來た

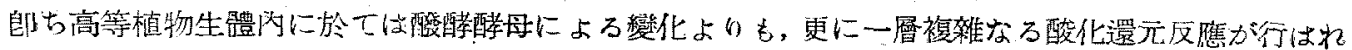
つっあることが登明された。

\section{嘪 驗 の 部}

昭和 16 年 6 月 10 日, 研究所肉にあるガジュマル2本を翼び地上 $1 \mathrm{~m}$ 附近の變形 Y 字形分枝の

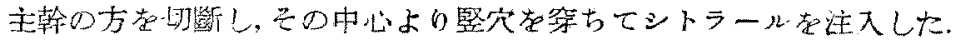

A は注入部の外圍 $49.5 \mathrm{~cm}$ であつてこのものに徑 $2.5 \mathrm{~cm}$, 長さ $35 \mathrm{~cm}$ の垂遖究学穿ち $150 \mathrm{cc}$ のシトシール学注入, B は注入部の外圍 $47 \mathrm{~cm}$, このものに徑 $1.5 \mathrm{~cm}$, 長さ $30 \mathrm{~cm}$ の穴を穿つて 70

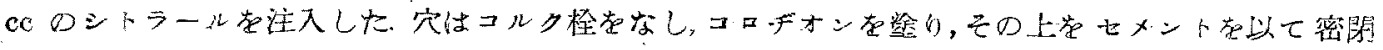

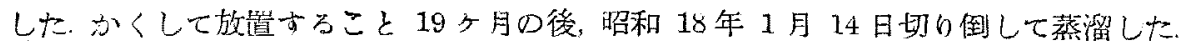

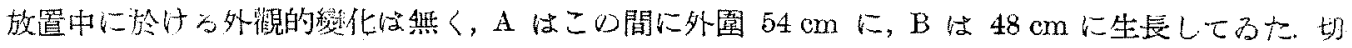

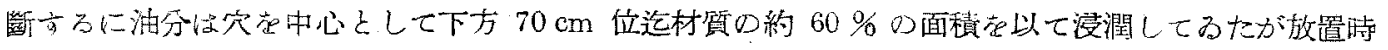

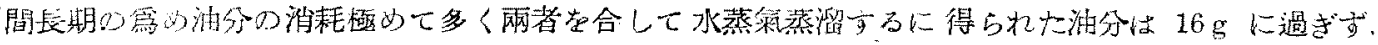

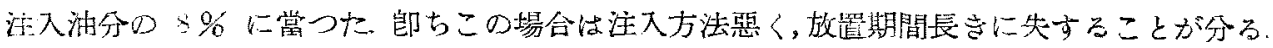

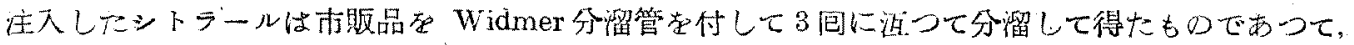
次の性質有有し大. 沸點 $118 \sim 119^{\circ} / 20 \mathrm{~mm} 、 226^{\circ} / 765 \mathrm{~mm}, \alpha_{4}^{30} 0.8832, n_{1}^{30} 1.4860, \alpha^{* 3} \pm 0.0^{\circ}$.

第 1 表

\begin{tabular}{|c|c|c|c|c|c|c|}
\hline 櫂 分 & 沸點/20 mm & 溜 至 $\mathrm{cc}$ & 渄盡/ $/ 768 \mathrm{~mm}$ & $d_{4}^{3 / 3}$ & $n_{D}^{20}$ & $\alpha_{\mathrm{D}}^{201}$ \\
\hline I & $74-110^{\circ}$ & 1 & $185^{\circ}$ & 0.8680 & 1.4535 & $+1.70^{\circ}$ \\
\hline II & $110-115^{\circ}$ & 2 & $217^{\circ}$ & 0.8883 & 1.4762 & $+0.7 x^{2}$ \\
\hline III & $115 \sim 116$ & 6 & $224^{\circ}$ & 0.8792 & 1.4775 & $+0.28^{\circ}$ \\
\hline IV & $116-118^{\circ}$ & 2 & $227^{\circ}$ & 0.8740 & 1.4745 & $-0.40^{\circ}$ \\
\hline $\mathrm{V}$ & 以上 & 2 & $229^{\circ}$ & 0.8748 & 1.4741 & -1.04 \\
\hline
\end{tabular}

1) Neuberg, Kerb: Biociem. Z., 92(1918), 1L1.

2) Fischer: Angew. chem. 53(1940), 465; "Fortschritte dex Org. Naturstotye", Iil. s. 33, 35. (1939).

3) Neuberg, Lewie: Biochem. L., 91(1918), 257. 
注入後の變化油は涨點 $223^{\circ} / 760 \mathrm{~mm}, d_{4}^{\mathrm{a0}} 0.8844, n_{\mathrm{D}}^{30} 1.4767, \alpha_{13}^{1 \mathrm{~s}}-0.24^{\circ}$ であつてシトラーグ臭弱く， 僅に左旋性に變化してるる.分溜の結果は第 1 表の樣である

\section{溜分IV; V}

これ等の溜分よ゙ら゙ラニオールとじトロネロールとの混合物よりなる.溜分 V の元素分析ば次の 樣で范る。

元弥分析：試料 $0,1095 \mathrm{~g}$

$$
\begin{array}{ccccc}
\mathrm{CO}_{2} \quad 0.3102 \mathrm{~g}, & \mathrm{H}_{2} \mathrm{O} & 0.1209 \mathrm{~g} ; & \mathrm{C} & 77.25 \%, \\
\mathrm{C}_{10} \mathrm{H}_{18} \mathrm{O} & \text { としての計算值 } & \mathrm{C} & 77.9 \%, \\
\mathrm{C}_{10} \mathrm{H}_{20} \mathrm{O} & \text { としての計算值 } & \text { C } & 76.9 \% ;
\end{array}
$$$$
\mathrm{H} \quad 12.34 \%
$$$$
\text { H } \quad 11.7 \%
$$

H $12.8 \%$

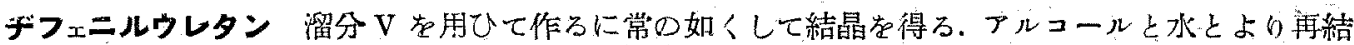
晶すれば融點 82〜83 の細かき針狀結晶となりゲラニオール・ヂフェニルウレタンに一致する。既知 物（融點 $81 \sim 82^{\circ}$ ）之混融するに全く同一物である。

元素分析：試料 $2.236 \mathrm{mg}$. $\mathrm{N}_{2} \quad 0.079 \mathrm{cc}\left(763.7 \mathrm{~mm}, 18.5^{\circ}\right) ;$
$\mathrm{C}_{23} \mathrm{H}_{27} \mathrm{O}_{2} \mathrm{~N} \quad$ と.Lての計算值
N $4.05 \%$

N $4.0 \%$

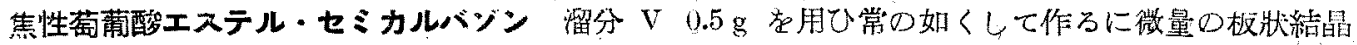

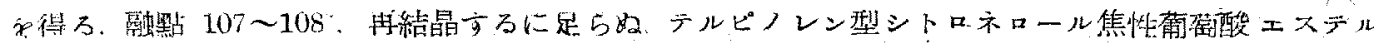

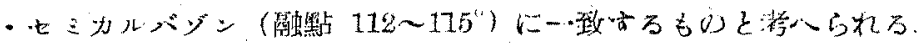

\section{留分 III, III}

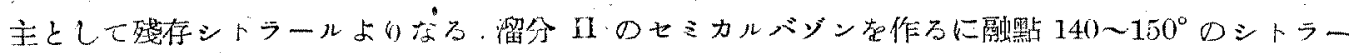

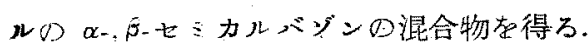

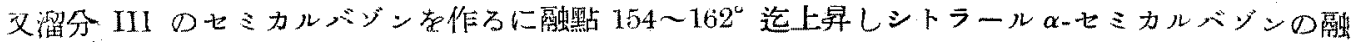
點 $164^{\circ}$ なる一致方る

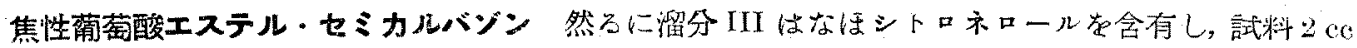

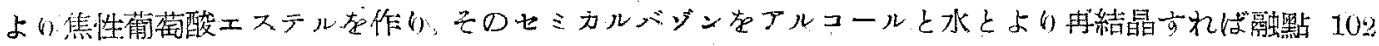
〜104であつてりモネン型シトロネロール焦性葡萄酸エステル・セミカルバダンに一致する。融點 102 104" ○稳知物と混融して證する。

元素分析: 試料 $0.882 \mathrm{mg}$.
$\mathrm{N}_{2} \quad 0.114 \mathrm{ce}\left(760.4 \mathrm{~mm}, 21.5^{\circ}\right)$;

$\mathrm{C}_{14} \mathrm{H}_{25} \mathrm{O}_{3} \mathrm{~N}_{3}$ としての計算值
N $14.74 \%$

N $14.8 \%$

溜分:

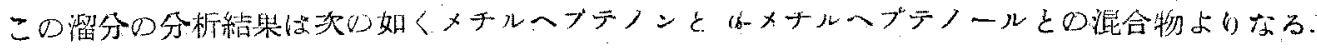

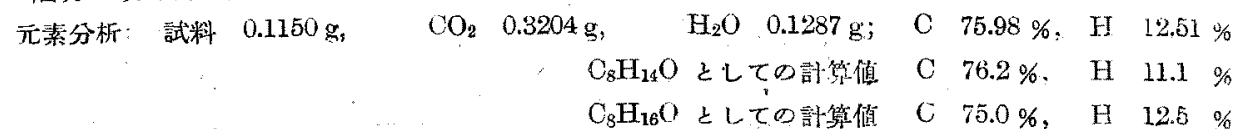

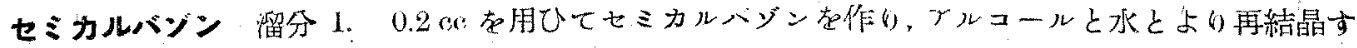

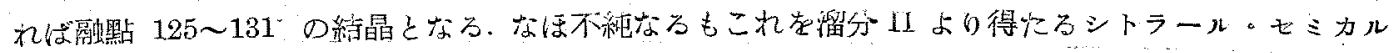

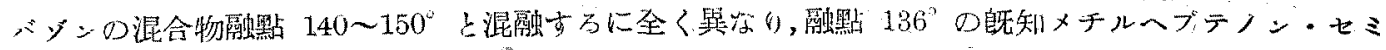
カルバジンと混融するに融點 133 〜 136 であつて同一物である.
元菜分析：試料 $0.756 \mathrm{mg}$.
$\mathrm{N}: 0.144 \mathrm{cc}\left(769.5 \mathrm{~nm}, 16.5^{\circ}\right)$;
N. $22.20 \%$
$\mathrm{C}_{9} \mathrm{H}_{77} \mathrm{ON}$ としての計算健
$\mathrm{N} \quad 22.9 \%$

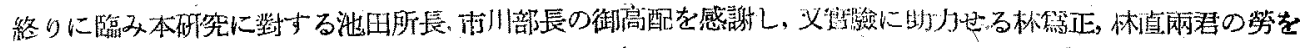
謝与 